UDC: $635.42-295.4 .028$

COBISS.SR-ID: 227888396

Original research paper

Acta Agriculturae Serbica, Vol. XXI, 41 (2016); 37-45

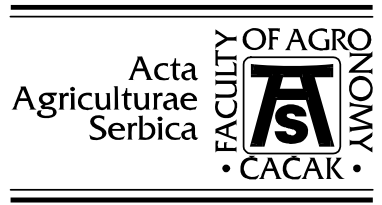

\title{
Persistence of pendimethalin residues in Swiss chard
}

\author{
Jelena Golijan $^{1}$, Dušan Stojanović ${ }^{1}$, Katarina Jovanović-Radovanov \\ and Aleksandar Popović ${ }^{2}$ \\ ${ }^{1}$ Faculty of Agriculture, University of Belgrade-Zemun, Belgrade, Serbia \\ ${ }^{2}$ Maize Research Institute, "Zemun Polje“, Belgrade, Serbia \\ *Corresponding author: e-mail: helena.ilios@gmail.com
}

\begin{abstract}
The aim of this study was to determine the persistence of pendimethalin and its impact on Swiss chard, as the succeeding crop in the crop rotation, using the bioassay method, by means of the morphological parameters measurement. In applying the tested concentrations of pendimethalin from 0.2475 to $3.96 \mathrm{ppm}$, the inhibition of certain measured parameters of the Swiss chard tested plants was demonstrated: root growth suppression in the range of 3.91 to $55.47 \%$, root fresh weight reduction from 5.56 to $55.56 \%$, reduction of shoot fresh weight from 2.2 to $44.35 \%$ and the reduction of fresh weight of the whole plant in the range of 2.5 to $46.17 \%$. Inhibition of the fresh root weight a the most sensitive parameter in relation to the applied rates of the herbicide, was demonstrated, while the shoot fresh=weight is a parameter that was not sensitive enough. Significant growth inhibition of all measured parameters was observed at pendimethalin concentrations above $0.99 \mathrm{ppm}$.
\end{abstract}

Key words: pendimethalin, inhibition, persistence, chard.

\section{Introduction}

Pendimethalin is a selective herbicide of the dinithroaniline class that plants absorb by roots and leaves. It inhibits the formation of microtubules by which the

Received: 4.4.2016. Accepted: 15.09.2016. 
cell division is ceased, after which plants dye immediately after germination (Janjić, 2005). Unlike other compounds, these compounds do not accumulate in plants and their organs. They are leached fast from the soil or are degraded in the process of denitration to the non-toxic final products (Xu et al., 2007). Pendimethalin degrades in the soil relatively slowly and this depends on the soil properties and climatic conditions (DT-50 $=72$ to 172 days). Degradation in the soil is done by oxidation of the 4-methyl group to carboxylic acid, dealklisaton of the amino groups and by the reduction of the nitro group (Kramer and Schirmer, 2007; Chopra et al., 2015).

The herbicide pendimethalin can be applied in three different ways (Kramer and Schirmer, 2007): 1) it can be incorporated prior to sowing, 2) after sowing but prior to emergence and 3) prior to transplanting or early after emergence in order to suppress annual grass and broad-leaved weeds in cereals, vegetables, planted fruits and lawns. The objective of this study was to observe persistence of pendimethalin by using the bioassay method, as well as its effects on Swiss chard as a succeeding crop in the crop rotation.

\section{Materials and methods}

The trial with the herbicide pendimethalin ( $N$-(1-ethylpropyl)-2,6-dinitro-3,4xylidine), preparation Zanat, intended for the commercial use (330 $\mathrm{g}$ a.i./l) was carried out under controlled conditions with the non-treated soil from experimental plots with degraded calcareous chernozem of the Maize Research Institute, Zemun Polje. Table 1 presents soil properties.

Table 1. Properties of calcareous chernozem in the location of Zemun Polje.

\begin{tabular}{|c|c|c|c|c|c|c|c|}
\hline \multirow{10}{*}{ 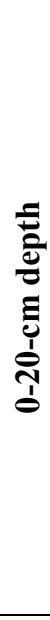 } & \multirow{2}{*}{$\begin{array}{l}\text { Hygroscopic } \\
\text { moisture \% }\end{array}$} & \multicolumn{6}{|c|}{ Fractions } \\
\hline & & \multicolumn{2}{|c|}{$\begin{array}{c}\text { Sand } \\
1.0-0.005 \mathrm{~mm}\end{array}$} & \multicolumn{2}{|c|}{ Silt $0.05-0.002 \mathrm{~mm}$} & \multicolumn{2}{|c|}{ Clay $<0.002 \mathrm{~mm}$} \\
\hline & 3.97 & \multicolumn{2}{|c|}{3.15} & \multicolumn{2}{|c|}{60.31} & \multicolumn{2}{|c|}{36.54} \\
\hline & \multicolumn{7}{|c|}{ Chemical properties } \\
\hline & \multirow[b]{2}{*}{$\% \mathrm{CaCO} 3$} & \multicolumn{2}{|c|}{$\mathrm{pH}$} & \multirow[b]{2}{*}{$\begin{array}{c}\% \\
\text { Humus }\end{array}$} & \multirow[b]{2}{*}{$\begin{array}{c}\% \\
\text { Nitrogen }\end{array}$} & \multirow{2}{*}{$\begin{array}{c}\text { Easy } \\
\text { accessible } \\
\mathrm{P}_{2} \mathrm{O}_{5} \\
\mathrm{mg} / 100 \mathrm{~g}\end{array}$} & \multirow{2}{*}{$\begin{array}{c}\text { Easy } \\
\text { accessible } \\
\mathrm{K}_{2} \mathrm{O} \\
\mathrm{mg} / 100 \mathrm{~g}\end{array}$} \\
\hline & & in $\mathrm{H}_{2} \mathrm{O}$ & $\begin{array}{c}\text { in } \\
\mathrm{KCL}\end{array}$ & & & & \\
\hline & 3.97 & 8.23 & 7.53 & 4.46 & 0.212 & 4.19 & 21.69 \\
\hline & \multicolumn{7}{|c|}{ Water and physical properties } \\
\hline & \multirow[b]{2}{*}{$\begin{array}{c}\text { Bulk } \\
\text { density } \\
\mathrm{g} / \mathrm{cm}^{3}\end{array}$} & \multirow[b]{2}{*}{$\begin{array}{l}\text { Density } \\
\mathrm{g} / \mathrm{cm}^{3}\end{array}$} & \multirow[b]{2}{*}{$\begin{array}{c}\text { Porosity } \\
\%\end{array}$} & \multicolumn{2}{|c|}{ Capacity } & \multirow[b]{2}{*}{$\begin{array}{c}\text { Wilting } \\
\text { moisture } \\
\%\end{array}$} & \multirow[b]{2}{*}{$\begin{array}{c}\text { Accessible } \\
\text { water \% }\end{array}$} \\
\hline & & & & $\begin{array}{c}\text { Field } \\
\text { capacity } \\
\%\end{array}$ & $\begin{array}{c}\text { Air } \\
\%\end{array}$ & & \\
\hline & 1.41 & 2.7 & 47.77 & 38.85 & 8.92 & 17.42 & 21.43 \\
\hline
\end{tabular}


Soil is low permeable with a coefficient of filtration of $6.83 \times 10^{-5} \mathrm{~cm} / \mathrm{s}$ at the $0-20-\mathrm{cm}$ depth. Swiss chard was used in the trail as a test plant. Prior to performing the trial the following series of solutions of pendimethalin of certain concentrations (calculated per $1 \mathrm{~kg}$ soil) was prepared: $0.2475 \mathrm{ppm} ; 0.495 \mathrm{ppm}$; $0.99 \mathrm{ppm} ; 1.98 \mathrm{ppm}$ and $3.96 \mathrm{ppm}$. The concentration of $3.96 \mathrm{ppm}$ of active substance corresponds to the maximum concentration applied in the field, plasticor glass-house and corresponds to the amount of 61 of preparation per hectare. The trial was performed in four replications and each replication in three different pots ( $200 \mathrm{ml}$ in volume) with the appropriate control treatments.

The procedure of bioassay started with measuring of $1 \mathrm{~kg}$ of the sieved soil for each concentration, followed by measuring of $10 \mathrm{ml}$ of a previously prepared herbicide solution of a certain concentration for the soil treatment. The application is done by a thin layer chromatography sprayer attached to a compressor, hence the complete amount of the herbicide was sprayed by a constant pressure of 1.2 bars and evenly spread over the whole sample soil area. After the application, the soil was first manually mixed, and then in the rotary blender at $60 \mathrm{rpm}$ for 5 minutes. The treated soil was arranged in the 200-ml pots. Six seeds of each test plant were sown and watered with $48 \mathrm{ml}$ tap water (up to field water capacity), and then placed in the growth chamber. Test Swiss chard plats were grown in the chamber for 14 days, on the average, under the following control conditions: 1) $6 / 8 \mathrm{~h}$ day/light regime, 2) temperatures: $22^{\circ} \mathrm{C}$ (day) and $18^{\circ} \mathrm{C}$ (night), 3) air humidity: $50 \%$ and 4) light intensity: $300 \mu \mathrm{E} / \mathrm{m}^{2} \mathrm{~s}$. Plants were watered each day with $10 \mathrm{ml}$ water in order to maintain the appropriate soil moisture. After taking out, roots were rinsed under running tap water, and then kept in water for a certain period, in order to remove of soil particles. Immediately prior to measuring, plants were wiped and dried between sheets of cotton paper.

The following parameters were measured in the experiment: root length, fresh weight of both roots and shoots. The initial diameter was determined for the each plant individually, and then the means were calculated. The final value was a mean for all replications. Remaining two parameters were measured as a cumulative value for all plants of one replication, and final value was a value for all replications. Parameters related to the weight are mean values obtained from the relation of the total weight of all plants in a given treatment and the number of plants. Based on obtained results, achieved inhibitions of measured parameters were estimated. Results of bioassay were read on Swiss chard plants after 13 days. Seeds were not additionally dressed, which resulted in sporadic occurrence of fungi of genera Pythium and Fusarium. The average values were calculated for each pot, each replication and a total mean value for each treatment and control.

The regression $\mathbf{y}=\mathbf{a}+\mathbf{b} * \mathbf{x}$ was used to describe the dependence of changes in measured parameters on changes in pendimethalin concentrations:

$\mathbf{y}-$ effect, i.e. $\%$ of inhibition for a measured parameter. 
$\mathbf{a}$ - average level of inhibition in the pendimethalin concentration equals null.

b - regression coefficient (also determines the slope of the regression line), i.e. how much is an average change in \% inhibition if pendimethalin concentration increases by $1 \mathrm{ppm}$.

$\mathbf{x}$ - pendimethalin rate.

Based on the regression equation, the $\mathrm{ED}_{50}$ values were estimated for all measured parameters. The statistical package Microsoft Office Excel 2003 was used for the estimation of regression equations and graphic presentation of the results.

\section{Results and Discussion}

Based on obtained results (Table 2) it is observable that the higher herbicide concentration was the lower germination was, and also the growth of Swiss chard was inhibited.

Table 2. Results - calculated mean values of the measured parameters by the specified concentrations of pendimethalin.

\begin{tabular}{ccccc}
\hline Concentrations & $\begin{array}{c}\text { Root length } \\
(\mathbf{m m})\end{array}$ & $\begin{array}{c}\text { Root fresh } \\
\text { weight } \mathbf{( g )}\end{array}$ & $\begin{array}{c}\text { Shoot fresh } \\
\text { weight } \mathbf{( g )}\end{array}$ & $\begin{array}{c}\text { Plant fresh } \\
\text { weight }(\mathbf{g})\end{array}$ \\
\hline Control & 32 & 0.018 & 0.093 & 0.111 \\
$0.2475 \mathrm{ppm}$ & 30.75 & 0.017 & 0.09025 & 0.10725 \\
$0.495 \mathrm{ppm}$ & 27.5 & 0.0145 & 0.0875 & 0.102 \\
$0.99 \mathrm{ppm}$ & 26 & 0.01325 & 0.084 & 0.09725 \\
$1.98 \mathrm{ppm}$ & 20 & 0.01075 & 0.06725 & 0.078 \\
$3.96 \mathrm{ppm}$ & 14.25 & 0.008 & 0.05175 & 0.05975 \\
\hline
\end{tabular}

Etiolation or whitening of Swiss chard leaves occurred at the lowest herbicide concentrations. Swiss chard plants in the soil with higher herbicide concentrations were subjected to the attack of soil pathogens. Inhibition of the following parameters of Swiss chard test plants was expressed when pendimethalin was applied in the concentration ranging from 0.2475 to 3.96 ppm: reduction in root growth in the range from 3.91 to $55.47 \%$ (Figure 1), reduction in fresh root weight (5.56-55.56\%. Figure 2), reduction in fresh shoot weight $(22-44.35 \%$, Figure 3$)$ and reduction in fresh weight of the whole plant (2.5-46.17\%, Figure 4).

Figure 5 presents the effect of pendimethalin on inhibition of all measured parameters in Swiss chard. In relation to the applied herbicide rates, inhibition of fresh weight of root was the most sensitive parameter. Based on the regression equation, $\mathrm{ED}_{50}$ values were estimated for all measured parameters (Table 3 ). 
Table 3. $\mathrm{ED}_{50}$ of measured parameters.

\begin{tabular}{lc}
\hline MEASURED PARAMETERS & ED $_{\mathbf{5 0}}(\mathbf{p p m})$ \\
\hline Root length & 3.2921 \\
Root fresh weight & 3.17668 \\
Shoot fresh weight & 4.29494 \\
Plant fresh weight & 4.0886 \\
\hline
\end{tabular}

Measurements of length and fresh weight of roots and shoots show that the fresh weight of roots was the most sensitive parameter with the strongest inhibitory effect by the herbicide.
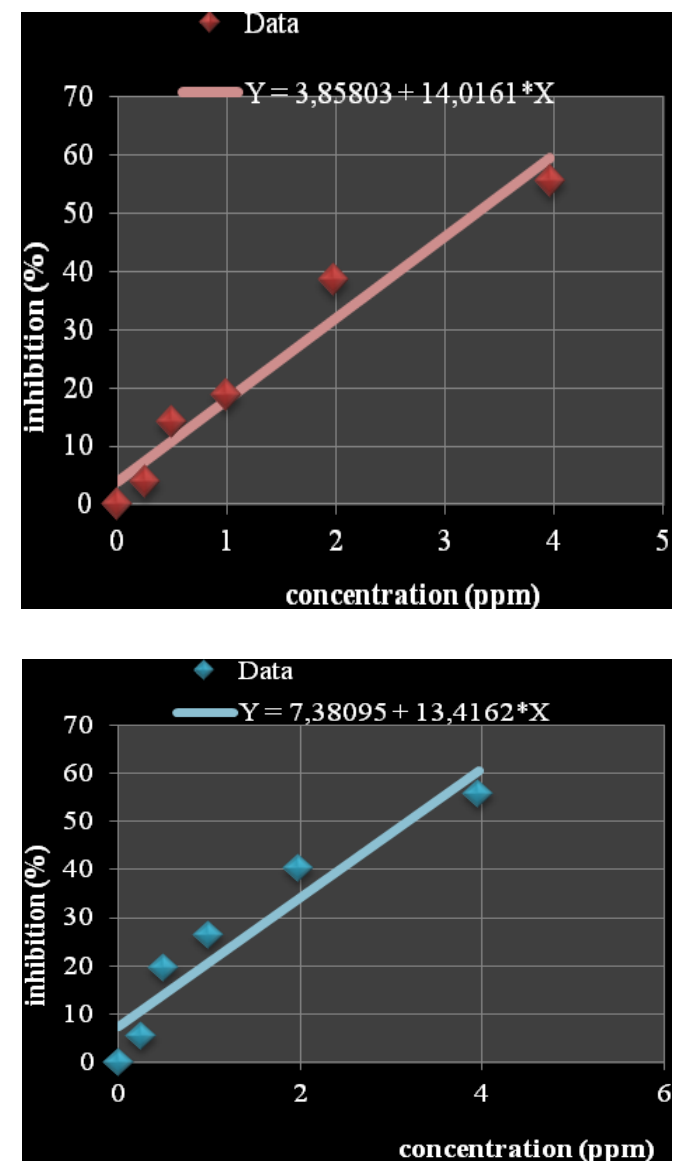

Figure 1. The impact of pendimethalin on inhibition of Swiss chard root length. $\mathrm{ED}_{50}=$ $3.2921 \mathrm{ppm}$

Figure 2. The impact of pendimethalin on inhibition of Swiss chard root fresh weight. $\mathrm{ED}_{50}=3.17668 \mathrm{ppm}$ 


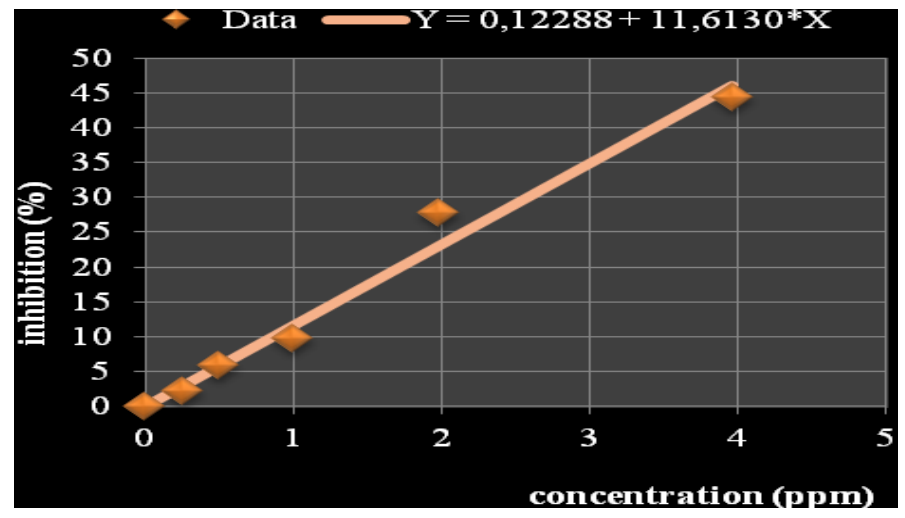

Figure 3.

Influence of

pendimethalin on

inhibition of

Swiss chard shoot

fresh weight.

$\mathrm{ED}_{50}=4.29494$

ppm

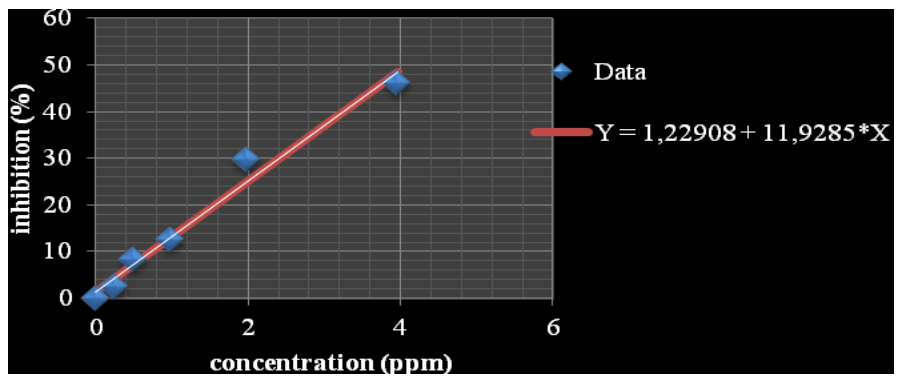

Figure 4. The

impact of

pendimethalin on

inhibition of

Swiss chard plant

fresh weight.

$\mathrm{ED}_{50}=4.0886$

ppm

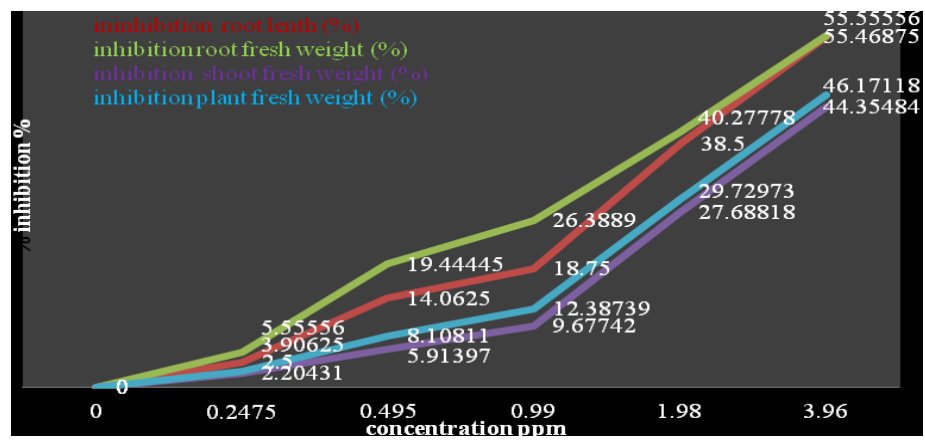

Figure 5. The

impact of

pendimethalin on inhibition of measured parameters in Swiss chard.

The significant increase in inhibition of all measured parameters is observed for the pendimethalin concentrations above $0.99 \mathrm{ppm}$, while lower concentrations had smaller effects on the reduction of measured parameters. Inhibition of the fresh weight of shoots showed to be the most unreliable parameter, especially with concentrations below $0.99 \mathrm{ppm}$, when a significantly slower increase of inhibition with increased pendimethalin concentrations was observed. At the same time, the fresh weight of shoots had the greatest $\mathrm{ED}_{50}$ value $(4.29 \mathrm{ppm})$. The root length was a relatively reliable parameter, particularly for the concentrations above $1.98 \mathrm{ppm}$ and $\mathrm{ED}_{50}$ values for this parameter. According to 
the stated, it is observable that the fresh weight of roots was the most sensitive parameter, although the root length provided reliable enough response.

Pendimethalin residues in the soil, determined by the bioassay under controlled conditions, can have phytotoxicity effects on Swiss chard (Shanmugasundaram and Kandasamy, 2003; Hatzinikolaou et al., 2004). Furthermore, it was determined that the increase in concentrations increased the expressed detrimental effect of this compound. At the concentration of $3.96 \mathrm{ppm}$, the following was observed: slight thickening of roots in the zone and a bit bellow the zone of the root collar, then narrowing of the leaf blade, accompanied by brittle leaflets that had become dark green. Furthermore, it was also observed that the higher concentrations of the herbicide resulted in a poorer formation of the secondary root system, inhibited growth and development of the whole plant, as well as a darker colour of leaf blades. In addition, it was noticed that the higher herbicide concentrations were the lower germination and more inhibited growth of Swiss chard were. Moreover, etiolation or whitening of leaves occurred even at the lower herbicide concentrations. Swiss chard plants in soil with higher herbicide concentrations were subjected to the attack of soil pathogens.

Applied herbicides maintain their properties and even their capacity to destroy weeds for a shorter or a longer period. This depends, first of all, on stability of herbicide molecules and this property is called persistence (Kramer and Schirmer, 2007; Sireesha et al., 2012). In certain cases, persistence provides herbicide activity in much longer period of time. Nevertheless, it can, at the same time, present danger for succeeding crops in the crop rotation that are susceptible to the effects of an appropriate herbicide or for humans and domestic animals if there are residues in final products intended for nutrition. Herbicide persistence is not an invariable. After four months of the herbicide application in the full amount of $61 /$ ha, which corresponds to the concentration of $3.96 \mathrm{ppm}$, a half of this concentration, i.e. $1.98 \mathrm{ppm}$, will still remain in the soil, which is a lethal concentration for the majority of crops in the crop rotation, as well as for weeds susceptible to effects of this herbicide. After eight months, the concentration of this herbicide in the soil will be approximately $0.8 \mathrm{ppm}$, which is still lethal for very susceptible plant species. This concentration will be about $0.37 \mathrm{ppm}$ after 16 months, which is an amount that inhibits measured parameters in Swiss chard, with the maximum inhibition of root fresh weight of $12.34 \%$ (Xu et al., 2007). Under certain conditions, persistence will increase with the increased rate of the applied herbicide. However, there is not linearity between these two phenomena.

Arora and Tomar (2008) have proven in their studies that observed parameters, such as height, fresh and dry weight of the plant, were significantly reduced under effects of pendimethalin even up to 75 days after its application. The plant height was lowered by $31.0,29.5,22.7,22.0$ and $8.5 \%$ in comparison with the control in the course of 15,30, 45, 60 and 75 days, respectively, after pendimethalin had been applied. Moreover, a similar trend in decreasing of fresh and dry weight was observed. Previous studies suggest that pendimethalin 
remains persistent in the soil cultivated with various crops up to 75 days after its application, and after this period there were no detected residues in the soil (Hatzinikolaou et al., 2004; Xu et al., 2007).

\section{Conclusion}

According to gained results on inhibition of all measured parameters it can be concluded that Swiss chard is very susceptible to observed compound. Besides, measured parameters differed in their sensitivity. The most sensitive parameter was fresh weight of roots, then root length, while shoot fresh weight was not a sufficiently sensitive parameter. Therefore, sowing of Swiss chard will be profitable in a certain plot if it is performed at least two years after the last application of pendimethalin in the full concentration (3.96 ppm).

\section{References}

Arora, A., Tomar, S. S. (2008): Persistence of pendimethalin in soil applied to different crops. Agricultural Science Digest, 28(4): 295-297.

Chopra, I., Chauhan, R., Kumari, B. (2015): Persistence of Pendimethalin in/on Wheat, Straw, Soil and Water. Bulletin of environmental contamination and toxicology, 95(5): 694-699.

Cutulle, M. A., McElroy, J. S., Millwood, R. W., Sorochan, J. C., Stewart, C. N. (2009): Selection of bioassay method influences detection of annual bluegrass resistance to mitotic-inhibiting herbicides. Crop science, 49(3): 1088-1095.

Hatzinikolaou, A.S, Eleftherohorinos, I.G, Vasilakoglou, I.B. (2004): Influence of Formulation on the Activity and Persistence of Pendimethalin. Weed Technology, 18 (2): 397-403.

Janjić, V. (2005): Fitofarmacija. Društvo za zaštitu bilja Srbije. Beograd-Banja Luka, pp. 778-779.

Kramer, W., Schirmer, U. (2007): Modern Crop Protection Compounds. WILEY-VCH Verlag GmbH \& Co. KGaA, Weinheim, Vol.1, pp. 317-332.

Shanmugasundaram, R., Kandasamy, O.S. (2003): Bioassay studies on the residual effect of herbicides applied. Department of Agronomy, Tamil Nadu Agricultural University, pp. 4-6.

Sireesha, A., Rao, P. C., Rao, P. V., Swapna, G., Ramalakshmi, C. S. (2012): Residues of pendimethalin and oxyfluorfen in radish and their persistence in soil. $J$ Crop Weed, 8(2): 120-125.

Xu, X., Wang, G. Q., Li, L. Z. (2007): Studies on the Herbicidal Activity of Pendimethalin [J]. Acta Agriculturae Boreali-Occidentalis Sinica, 4: 054. 


\title{
PERZISTENTNOST OSTATAKA PENDIMETALINA U BLITVI
}

\author{
Jelena Golijan $^{1}$, Dušan Stojanović ${ }^{1}$, Katarina Jovanović-Radovanov ${ }^{1}$ i \\ Aleksandar Popović ${ }^{2}$ \\ ${ }^{1}$ Poljoprivredni fakultet, Univerzitet u Beogradu-Zemun, Srbija \\ ${ }^{2}$ Institut za kukuruz "Zemun Polje", Beograd, Srbija \\ e-mail: helena.ilios@gmail.com
}

\begin{abstract}
Rezime
Cilj ovog rada je bio da se utvrdi perzistentnost pendimetalina i njegov uticaj na blitvu kao narednu gajenu biljku u plodoredu korišćenjem biotest metode, merenjem morfoloških parametara. Pri primeni ispitivanih koncentracija pendimetalina od 0,2475 do 3,96 ppm ispoljena je inhibicija određenih merenih parametara blitve kao test biljke: redukcija rasta korena u rasponu od 3,91-55,47 $\%$, redukcija sveže mase korena 5,56-55,56 \%, redukcija sveže mase izdanka 2,2$44,35 \%$ i redukcija sveže mase cele biljke u intervalu od 2,5-46,17 \%. Kao najosetljiviji parametar, $u$ odnosu na primenjene doze herbicida, pokazala se inhibicija sveže mase korena, a sveža masa izdanka predstavlja parametar koji nije dovoljno osetljiv. Značajni porast inhibicije svih merenih parametara uočava se pri koncentraciji pendimetalina iznad 0,99 ppm.
\end{abstract}

Ključne reči: pendimetalin, inhibicija, perzistentnost, blitva. 